\title{
'Let no one say the past is dead': History wars and the poetry of Oodgeroo Noonuccal and Sonia Sanchez
}

\author{
Ameer Chasib Furaih \\ ameerchasib.furaih@griffithuni.edu.au
}

\begin{abstract}
The histories of Australian Aboriginal and African American peoples have been disregarded for more than two centuries. In the 1960s, Aboriginal and African American civil rights activists addressed this neglect. Each endeavoured to write a critical version of history that included their people(s). This article highlights the role of Aboriginal Australian poet Oodgeroo Noonuccal (formerly Kath Walker) (1920-93) and African American poet Sonia Sanchez (born 1934) in reviving their peoples' history. Using Deleuze and Guattari's concept of 'minor literature', the essay shows how these poets deterritorialise the English language and English poetry and exploit their own poetries as counter-histories to record milestone events in the history of their peoples. It will also highlight the importance of these accounts in this 'history war'. It examines selected poems from Oodgeroo's My People: A Kath Walker Collection and Sanchez's Home Coming and We A BaddDDD People to demonstrate that similarities in their poetic themes are the result of a common awareness of a global movement of black resistance. This shared awareness is significant despite the fact that the poets have different ethnicities and little direct literary impact upon each other.
\end{abstract}

\section{Introduction}

During the 1960s and 1970s, Aboriginal Australian and African American civil rights campaigners redefined their position in accounts of the past as part of a wider campaign of decolonisation. The struggle to be recognised as full citizens of their postcolonial nations involved a review of the historical record and a reconsideration of their position in it. The neglect of black perspectives was not only a function of historical 'forgetting'; it was also a function of language. English has always played a role in it. In Australia, the early European settlers utilised English, or AusE, to hide 'rupturings of self, place and history' (Mead 2008: 409). It is AusE, not Aboriginal English, that is officially used in writing the dominant history. ${ }^{1}$ In the United States, English has a comparable official position and role. The federal government has formally adopted Standard English, not African American Black English, in writing 
history, and this historical mono-perspective has marginalised not only the history of African American peoples, but also the history of the Indigenous peoples of America (see Hill 2006). Accordingly, Aboriginal and African American peoples 'have had to assert their identity in opposition to the processes of identification or annihilation triggered by these invaders', to use the words of Caribbean poet and critic Édouard Glissant (2010: 17).

Aboriginal poet Oodgeroo Noonuccal (formerly Kath Walker) (1920-93) and African American poet Sonia Sanchez (born 1934) were - and Sanchez still is crucial combatants in these 'history wars'. These poets 'remember against the grain ... [and their] memories do not fit the historical narratives available' (Medina 2011: 12). Both resist the erasure and misrepresentation of their peoples' postcontact histories in the dominant narratives of their respective countries. They collaborated with political activists who demanded 'education that teaches us our true history' (cited in Lothian 2005: 187). These poets' positions have much in common with the writings of Franz Fanon (1963: 51), who urged the colonised peoples 'to put an end to the history of colonization ... and to bring into existence ... the history of decolonization'.

This essay demonstrates how Oodgeroo and Sanchez exploit their poetries as counter, decolonising narratives to the European-generated (post)colonising historical and quasi-historical discourses. In discussing their poetries as a combination of seemingly two different fields of study (history and poetry), I draw on The Art of Time Travel: Historians and Their Craft by Australian historian Tom Griffiths (2016). Griffiths examines the works of fourteen different writers of history, including literary writers such as Eleanor Dark, Kate Grenville and Judith Wright, to highlight that historians are not the only writers of history. Likewise, Oodgeroo and Sanchez rewrite historical ideas and reposition the historical narrative so that it is not dominated by 'whiteness'. However, discussing the histories of Aboriginal and African American peoples here does not suggest that these peoples can be seen to constitute one people. Each has their own diverse experiences, ethnic qualities, religious values, cultural mores and languages. Their experiences with the 'white' settlers are not identical. Indigenous Australians have been dispossessed of their country; African Americans were deported to the United States as slaves from Africa. Accordingly, the motives behind their resistance to dominant histories are not identical either.

\section{Oodgeroo Noonuccal}

In a speech delivered at Griffith University in 1989, Oodgeroo argued that 'Australian history books assert that Aboriginal and Australian history began in 1770 ... We are also urged to believe that our Aboriginal political existence began on 27 May 1967, with the referendum' (Cochrane 1994: 204). This conflation ${ }^{2}$ of Aboriginal 'Dreamtime' and 'white history' is both an oversight and misrepresentation of the First Nations' pre- and post-contact history. In 1968, the remarkable finding of Aboriginal cremation at Lake Mungo, which dated back 'twenty thousand years,'3 argues Muecke (2004: 25), 'had the effect of stretching national time back into the distant past'. It seems that this discovery enabled Oodgeroo to argue against existing concepts of nationhood and sovereignty. For her, the past should not be 
comfortable; it should be disturbed all the time to uncover the hidden stories. In 'The Past', she writes:

Let no one say that past is dead.

The past is all about us and within.

Haunted by tribal memories, I know

$[\ldots]$

The poem continues:

Deep chair and electric radiator

Are but since yesterday,

But a thousand thousand camp fires in the forest

Are in my blood.

Let none tell me the past is wholly gone.

$[\ldots]$

(Walker 1970: 94)

This poem can be seen as a 'countermemory', ${ }^{4}$ which looks to the past for the hidden histories excluded from dominant narratives. The first and last lines of this poem remind us of American writer William Faulkner's assertion that, 'The past is never dead. It's not even past' (cited in Griffiths 2016: 5). Armed with her 'tribal memories', Oodgeroo identifies some of the main milestones of her people's (post)-contact history in her poetry. This includes the European invasion of the continent and subsequent massacres, slavery, and the destruction of Aboriginal cultures and languages through imposing protection and assimilation policies. 'The Dispossessed' is one example:

Peace was yours, Australian man, with tribal laws you made,

Till white Colonials stole your peace with rape and murder raid;

They shot and poisoned and enslaved until, a scattered few,

Only a remnant now remain, and the heart dies in you.

The white man claimed your hunting grounds, and you could not remain,

They made you work as menials for greedy private gain;

Your tribes are broken vagrants now wherever whites abide,

And justice of the white man means justice to you denied.

They brought you Bibles and disease, the liquor and the gun:

With Christian culture such as these the white command was won.

A dying race you linger on, degraded and oppressed,

Outcasts in your own native land, you are the dispossessed.

$[\ldots]$

(Walker 1970: 65)

This poem is structured by binary oppositions such as peace/war, us/you, precolonial/postcolonial periods and Indigenous culture(s)/Christian culture. These binaries are meant to establish the impact of the invasion of the continent by the European colonists. This poetry is a decolonising force because it contests the assumptions of 'white' history.

Oodgeroo refers to the pre-colonial period when Aboriginal peoples lived in peace and harmony. The advent of the European colonists destroyed the peaceful life of Aboriginal peoples 'with rape and murder raid'. In the frontier period, colonial policing was involved in this violence. The police (including native police), 
assigned to protect the settlers as well as Indigenous peoples (protectionism), executed violent 'murder raid[s]'. They attacked Aboriginal warriors, who resisted dispossession of land and resources as well as disruption of their traditional life. The police's aggressive actions were 'largely devoid of either judicial or public review' (Cunneen 2001: 46), and, therefore led to the reduction of the Aboriginal population, who were subsequently considered a 'dying race'. The word 'scattered' may refer to the scattering of Aboriginal families through, for example, the 'Stolen Generations', the scattering of the Indigenous cultures through assimilation and/or the scattering of their country into states. The scattering also led to the loss of their country and their subsequent exploitation as under-paid workers. The word 'disease' might be interpreted as a physical disease brought by the settlers or a social one, such as racial discrimination.

The themes in 'The Dispossessed' resonate with Oodgeroo's other poems. The poem's reference to the raping of Aboriginal girls is echoed in 'The Protectors': 'Is there rape of dark girl by white man or men/ There is no question even of inquiry' (Walker 1970: 28). Because the assimilation policy sought to 'genetically eliminate the native populace' to use the words of Kat Ellinghouse (cited in Foley 2000: 1), Oodgeroo opposes it by juxtaposing her people's 'tribal laws' with the colonists' 'Christian culture'. Similarly, in 'Assimilation - No!', the poet argues, 'Do not ask us/ To be deserters, to disown our mother/ To change the unchangeable' (Walker 1970: 22). This is why, in 'Son of Mine (To Denis)', she celebrates the beauty of her people's black skin: 'Your black skin soft as velvet shine' (Walker 1970: 55). In 'The Teachers', the poet uses irony to disparage the missionaries who came during the mid-nineteenth century 'to civilize and Christianise the indigenes' (Attwood and Markus 1999: 8):

Holy men, you came to preach:

'Poor black heathen, we will teach

Sense of sin and fear of hell,

Fear of God and boss as well'

$[\ldots]$

(Walker 1970: 26)

In 'The Protectors', the poet criticises the Central Board for the Protection of the Aborigines during the nineteenth and early twentieth centuries (Attwood and Markus 1999): 'At the request of the graziers and their wives/ We feel like owned animals of the Sergeant/ The protector who does not protect' (Walker 1970: 28). In 'Aboriginal Charter of Rights', she mentions various forms of injustices, which have been imposed upon Aboriginal peoples since 1788, such as 'racialism', 'ostracism', 'subjection', 'protection', 'settlements and missions', 'discrimination' and 'crucifixion' (Walker 1970: 36).

\section{Sonia Sanchez}

In her poetry, Sanchez has been on a parallel but distinct trajectory. During the 1960s, she resisted the narratives that promoted the binary of 'black' non-being and 'white' human-being. Her poetry was an integral part of the Civil Rights Movement. In Between the World and Me, Sanchez's student Ta-Nehisi Coates (2015) tells his son about how his grandparents (Coates's parents, who were radical 
activists during the 1960s and 1970s), resisted the mainstream history that aimed to degrade African American people. Coates (2015: 43-4) argues that, 'Our history was inferior because we were inferior, which is to say our bodies were inferior. And our inferior bodies could not possibly be accorded the same respect as those that built the West.'

The teachings of Elijah Mohammed of the Nation of Islam (NOI) influenced African American activists during this period. Malcolm X (1965: 110) argues that in the lesson called 'Yacub's History', Muhammed teaches his followers that 'the first humans, Original Man, were a black people. They founded the Holy City Mecca'. This claim extends the 'black' race's history beyond the limits of American 'white' history, which started with Columbus landing on the shores of the New World in 1492.

In her poetry, Sanchez revisits the Atlantic slave trade, plantation life, lynching, Jim Crow laws, systematic socio-political marginalisation and state-sanctioned violence. In her poem 'To Fanon, culture meant only one thing', ${ }^{5}$ the poet connects past and contemporary events in her people's history:

$[\ldots]$

the cracker is deep

deeper than the

400 yrs of our slavery.

we must

watch our

slavery

especially when it looks like freedom.

cuz slaves can look beautiful, talk beautifullee

can be deceived by the DEVIL

$[\ldots]$

mas/ter/ful.

the master is

is the SUPREME ANIMAL of

destruction and cannot be destroyed with only:

long dresses - swahili - curses - soul food -

fervor - dashikis - naturrrals - poems -

SOUL - rage - leather jackets - slogans-

polygamy - yoruba.

NO. WE NEED.

WAR. DISCIPLINE. LEARNIN.

LAND. PLANNEN. LOVE. AND

POWER. POWER. blacker than the smell of death

to destroy we the hunters need

the BEAST

who enslaves us.

(Sanchez 1970: 50-1)

Slavery dramatically transformed the life of African American people. Malcolm X (1965: 108) describes it as '[h]uman history's greatest crime'. In this poem, Sanchez associates the early chattel slavery (the treatment of slaves as a possession of the owner) with the subsequent cultural, social and political forms of slavery that her people continue to experience. She makes this association clear as she 
ends the poem with the present tense verb 'enslaves'. This is to convey the idea that 'slavery' or 'modern slavery' is an unchanging fact and that the 'Emancipation Proclamation' of the late nineteenth century is a fiction: 'we must/ watch our/ slavery/ especially when it looks like freedom.' The poet aims to raise 'Black' consciousness. She claims that 'white' supremacy, or 'the evilllll ... cannot be resolved thru rhetoric/ hate/ poems', cultural revival ('long dresses - Swahili curses - soul food - fervor - dashikis'), or 'leather jackets' (a common mode of Black Power activists' dress). The criticism here may be directed at the civil rights campaigners and their non-violent strategies. Martin Luther King Jr. claimed that the phrase 'Black Power' 'falls on the ear as racism in reverse' (Martin 1991: 84). Instead, Sanchez calls for actual, radical solutions to her people's plight. She prefers action, confrontation, revolution: 'POWER. POWER. POWER blacker/ than the smell of death' and a 'land' to achieve independence and 'real' emancipation. Her criticism of passive resistance is further emphasised in her elegy 'malcolm': 'do not speak to me of martyrdom/ of men who die to be remembered' (Sanchez 1969: 15, italics mine).

This is why Sanchez identifies radical African American people with 'the cracker'. In addition to other symbolic interpretations of this symbol, the cracker is 'a tube of coloured paper that makes a loud, explosive sound when it is pulled open by two people' ('Cracker' 2017). When she metaphorically states that 'the cracker is deep/ deeper than the/ 400 yrs of our slavery', she refers to the explosive (revolutionary) potentialities of African American people if they have not truly been emancipated. The phrase 'deeper than the / 400 yrs' seems a deliberate attempt to extend African American history beyond the borders of the New World. It also can be used to refute any racist claim that 'Africa was the only continent that produced no history', to use the words of Arnold Toynbee (cited by Malcolm X 1965: 116). Sanchez refers to people of the distant African past and their heritage as 'hunters' so as to demonstrate that they are not helpless and can resist the 'oppressor', 'the BEAST'. The same idea of dignifying the glorious African past is repeated in her 'poem (for dcs 8th graders - 1966-67)'. Here, the poet dignifies African 'slaves' as 'black warriors', whose rebellious deeds on board the slavery ships are linked to Malcolm X's struggle for his people's human rights during the 1960s:

look at me 8th

grade

$[\ldots]$

on my face

are black warriors

riding in ships

of slavery;

on my face

is malcolm

spitting his metal seeds

on a country of sheep;

[...]

(Sanchez 1969: 22-3)

Describing African American people as 'black warriors' is meant to transform the stereotypical view of African slaves as 'passive' and 'helpless' people, whose lives 
were improved by the 'white' emancipation. In fact, they played an important role in their 'self-emancipation' (Berlin 2010: 1). Berlin's position is supported by events such as the revolt of some African slaves and the construction of their independent maroon colonies during the antebellum period (Eaton 2008). This poem seeks to correct this distorted history.

In 'right on: wite America', Sanchez refers to her people's 'blk / deaths', which can be seen as a reference to the lynching of African American people by Ku Klux Klan in the American South during the nineteenth and twentieth centuries (Waldrep 2009):

$[\ldots]$

a / mer / ica /

is now killing her own

after all the

of our

terrible / blk / deaths /

terrible / blk / yrs.

(We A BaddDDD People, p. 26)

In '221-1424 (San/francisco/suicide number)', the poet refers to this unchanging reality: 'HONKIES / were tryen to kill me?/ [ ... ] it's been happenen/ for bout 400 yrs' (Sanchez 1970: 12).

Like Oodgeroo, Sanchez is conscious of the destructive impact of the dominant culture on her people's cultures and languages because the 'white supremacy' urged black people to 'negate blackness, [and] to imitate racist white people so as to better absorb their values, their way of life' (hooks 1995: 186). Like Oodgeroo's 'Son of Mine (To Denis)', Sanchez's 'poem (for dcs 8th graders - 1966-67)' invokes the ideals of 'The Black is Beautiful' movement to resist this policy:

look at me 8 th

grade

i am black

beautiful. i have a

man who looks at

my face and smiles.

$[\ldots]$

(Sanchez 1969: 22)

In 'small comment', the poet links the 'white' supremacist ideology to Darwinian evolutionary theories, whose notions of 'the survival of the fittest' and 'natural selection', were 'soon misused to legitimize inhuman competition, racism, and the extermination of other races' (Lindquist 1997: 77):

[...]

the nature of nature is

the bestial survival of the

fittest the strongest the richest

or to really examine

the scene we cd say that

the nature of any beast is

bestial unnatural and natural 
in its struggle for superiority

and survival

[...]

(Sanchez 1969: 17)

Sanchez's poem 'the final solution' moves to contemporary history to talk about the participation of African American soldiers in the Vietnam war in 1968:

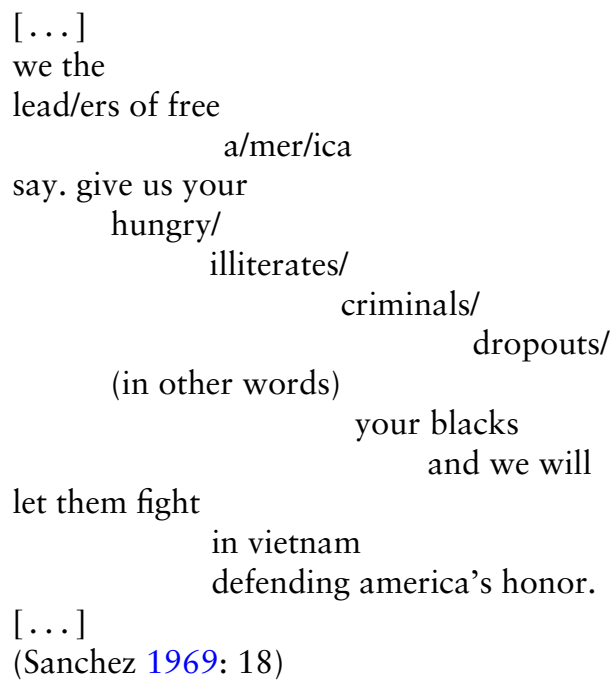

In an ironic tone, the poet talks about the double-speak of American politicians. They sent African American soldiers, among other troops, to fight an overseas war in Vietnam. According to the poet, these politicians intended to build their glory at the expense of African American lives.

\section{Historicising appropriated poetics}

Through poetry, Oodgeroo and Sanchez create a sovereign space where they can engage dominant history in poetic debate. This poetics moves against the established literary traditions in their respective countries. This violation enabled them to transgress literary boundaries so that they could transform their poetries into counter-histories. The poets' opposition to or 'appropriation' of the English language and poetry differ, however. The concept of a 'minor literature' proposed by Deleuze and Guattari (1986) is helpful in elucidating this revolutionary poetics. They argue (1986: 16-17) that a 'minor literature' has three distinctive characteristics: its language is affected with a 'high coefficient of deterritorialization'; its content is predominantly connected to a 'political immediacy'; and and its enunciation is 'collective'. They extend the definition of the minor literature from the one that is written by a minority using the majority's language to that which 'no longer designates specific literatures but the revolutionary conditions for every literature within the heart of what is called great (or established) literature' (1986: 18). Approaching Oodgeroo and Sanchez's poetries as a 'minor literature' is one way to think differently about their poetic contribution to their peoples' 'history war'. This concept can be used to frame our thought and discussion, and to help us 
avoid being weighed down by fixed images or by the old categories of genres, types and modes of literary production, because 'it allows one to dispense with dualisms and rifts ... that have ultimately constituted a sort of vulgate' (Bensmai'a 1986: $\mathrm{xv})$. Oodgeroo and Sanchez 'expanded' the literary canon. They created a literary world where boundaries are flexible, one that is not hostile to the representation of a minority.

Deleuze and Guattari's (1986) discussion of the work of Franz Kafka can usefully be applied to the poetry of Oodgeroo. Like Kafka's 'Prague German', Oodgeroo deterritorialises English through shifting its boundaries to express her people's voice. Her 'minor' poetry 'affects the language in which it is affected' (Deleuze and Guattari 1986: xvi). Speaking of this hybridity, Eva Rask Knudsen (1994: 11) states that Oodgeroo was obliged to 'master the conqueror's standard language to get her message across and avoid the danger of "thinking white". Oodgeroo appropriates English to record her people's history. For her, 'it is the master's rules, not his tools that are the problem: starting from rule one, the tools are his and should only be used as and when he directs' (Hodge 1994: 68). Oodgeroo uses English 'as and when [she] directs'. She uses it in a way that meets her socio-political demands: breaking the 'silence' and highlighting the destructive effect of long-term colonisation, dispossession, oppression and discrimination. Reviving her people's history, Oodgeroo becomes a spokesperson of her people. She not only presents events that are relevant to her people's lives, but also depicts them according to her people's perspectives: 'I thought poetry would appeal to them more than anything else. It was more of a book of their voices that I was trying to bring out, and I think I succeeded in doing this' (Oodgeroo, cited in Shoemaker 2004: 186). Thus the 'enunciation' of her poetry is 'collective'.

Oodgeroo's deterritorialisation of the English language also leads to the deterritorialisation of English poetry. In other words, when Oodgeroo adapts English to depict her people's post-contact situation, English poetry as a literary genre is deterritorialised because this representation transgresses fixed, hierarchical literary boundaries. According to the British, European and American literary canon, a literary work is considered a 'great art' or 'universal' only when its form and content resemble an already recognised 'great' European literary work that deals with only European experience (Tyson 2006: 361). Universalism, informed by the 'arborescent model of thought' (Deleuze and Guattari 1987: xii), encourages the reproduction of 'fixed representation'. Oodgeroo's depiction of her people's ('non-universal') history breaks this concept. This kind of poetry meets the second characteristic of a minor literature: its content is predominantly connected to a 'political immediacy'. In addition to contesting the dominant history, her poetry presents a deconstructionist critique that reverses the poles. Instead of glorifying the European settlers as the builders of the nation, she refers to them as 'colonists', while referring to her peoples as 'hunters' and 'tribal people'. Through this political move, Oodgeroo adopts another anti-Eurocentric position, especially with regard to the concept of 'the art for art sake'. According to Judith Wright (cited in Fox 2008: 62), 'If there was one forbidden territory in poetry in the era in which Oodgeroo began writing it was "propaganda and protest" literature, especially in verse.' Early mainstream reviewers of her first book of poetry We are Going (Walker 1964) approached her poetry negatively. In 1964, an anonymous reviewer claimed that 'This is bad verse ... This may be useful propagandist writing 
... [or] powerful social-protest material ... But this has nothing to do with poetry' (cited in Shoemaker 2004: 182).

In her interest in her people's history, Sanchez followed a path parallel to that of Oodgeroo. She experienced a comparable situation to that of Kafka and Oodgeroo regarding the acquisition of non-native, foreign language, which she uses to contest the dominant history. She was influenced by the writings of Fanon and his call to bring existence 'the history of decolonization'. Regarding the content of her poetry, representing African American history also moves against Western literary traditions and the concept of universalism. Like Oodgeroo, Sanchez presents a deconstructionist critique against the racial and racialist views of African Americans as 'Other', and of 'Europe as the source of knowledge', which caused 'many epistemological errors' (Cooke 2013: 2). While idealising African Americans as 'black warriors' and 'hunters', Sanchez refers to the American racists as 'BEAST', 'DEVIL', 'HONKIES' and 'crackers'. This also aligns her poetry with the characteristics of minor literature, namely 'language deterritorialisation', 'collective enunciation' and 'political immediacy' (Deleuze and Guattari 1986).

By highlighting these commonalities in the poetries of these two ethnically different poets, I am not claiming that their poetries can be compressed into one uniform poetry, however. Each poetry has its own characteristics, which are derived from different socio-political and cultural backgrounds. Sanchez expresses her views in a poetry that is structurally at odds with the established Western literary traditions, as in this example:
a / mer / ica /
is now killing her own
after all the

terrible / blk / deaths /

of our

terrible / blk / yrs.

Sanchez moved beyond the poetics of appropriation. While Oodgeroo adopted English and violates the 'master's rule' in her poetry, she wrote according to 'contemporary white models, and used metrical and rhyming patterns of the nineteenth and early twentieth century' (Neumann 1992: 292-3). Sanchez did not aim to 'master ... the standard language to get her message across and avoid the danger of "thinking white". Apparently, she had a 'problem' with the 'master's rules [and] tools', and thus adopted an anti-language and anti-poetry position.

This radical literary position resulted from the fact that she was a distinguished member of the African American Black Arts movement, a politically motivated movement that extended from the mid-1960s until the mid-1970s. This radical movement promoted 'Black aesthetics' and aimed at 'disfiguring' or 'discarding' many of 'the conventions of Western poetics' (Pate 2010: 20). Sanchez shared the radical literary ideology adopted by the Black Arts writers, such as Don L. Lee, who announced that '[w]e must destroy Faulkner, dick, jane, and other perpetuators of evil. It's time for DuBois, Nat Turner, and Kwame Nkrumah' (cited in Neal 1968: 29-30). Like Oodgeroo, Sanchez, among the Black Arts writers, was underestimated by dominant critics (see Frost 2005: 70). Sanchez's radical poetry was motivated by the assassination of Malcolm X and her involvement in the Black Power movement (Frost 2005: 71; Melhem 1985: 81; Sitter 2001: 357). She aimed 
at dismantling the 'white thing' or way of thinking to freely debate dominant history. Her anti-language position can be seen as a way to deform the tool that was used in deforming her people's history. This poetic disfiguration enabled her to adopt black aesthetics. She represents her people's history using vernacular language, which gives authenticity to the historical events in her poetry.

Oodgeroo and Sanchez transform their poetries into counter-histories to reveal the 'rupturings' that characterised their peoples' post-contact histories. This poetic deterritorialisation leads to the deterritorialisation of the dominant narratives in their countries because these poets represent stories of already disenfranchised peoples. Furthermore, these poets refute claims that the missions were constructed for the benefit of Aboriginal peoples, and that both Aboriginal and African American peoples were 'sub-human' and that their 'slavery' [was] both expedient and right,' to use the words of Aristotle (Ruchames 1970: 1).

Oodgeroo and Sanchez, however, distance themselves from contemporary historians, who often present fact-based narratives using more expansive and wellstructured language. Oodgeroo's and Sanchez's poetic language is less expansive and more condensed, and Sanchez sometimes dismantles the rules of English. This can be seen as a way to evade the sequential normative language embedded in the dominant histories. Oodgeroo's and Sanchez's responsibility is not to passively delineate the past events of their peoples' histories. They have more space for subjectively discussing mythical or emotional truths about their peoples. They use their artistic licence to convey ideas beyond mere facts. They poeticise these facts in a way that awakens political consciousness. For example, in 'Namatjira', Oodgeroo writes: 'Namatjira, they boomed your heart/ They called you genius, then broke your heart' (Walker 1970: 64). The poetry's shortness of form, condensation and musicality make the representation of history more effective and memorable.

Moreover, the structure they follow in representing these events is a nontraditional one, and it is poetry as a literary genre that helps them in this respect. These poets do not chronologically represent their peoples' histories in, say, one or two epic poems. Each of their relatively short poems represents a selected event or events. In their anthologies, these poems are not arranged in a chronological order according to the occurrence of the historical events. The reader can start from the beginning or wherever they prefer, depending on their poetic taste. The result is that their poetries represent non-chronological narratives. What makes their history-poetry significant is the unique Aboriginal and African American poetic lenses through which these poets reflect upon historical events.

Although Oodgeroo and Sanchez borrow the language and literary forms of the dominant culture, their appropriated poetries can be seen as examples of a (postcolonial) poetics that 'continue[s] to resist ... fusion', to use the words of Cooke (2013: 6, italics in original). Literary 'fusion' leads to a literary containment conditioned by systematic classification according to a pre-set 'universal' culture or literary works. The works of these poets are not passive components of literature, but active, revolutionary ('minor') poetries, which add to the existing diversities of genres. The works of these poets have their own unshaken literary identities, idiosyncratic addressers and addressees, and the reader may have the impression that English poetry has been given a new face. It should be noted, however, that the poetries of these poets are hybrid poetics and are parts of the dominant literatures 
in their respective countries. They write from a minority position, using a majority language: 'A minor literature doesn't come from a minor language; it is rather that which a minority constructs within a major language' (Deleuze and Guattari, 1986: 16). The adjective 'minor' is not meant to express negativity. Deleuze and Guattari consider minor literature as 'great literature' because it does not passively surrender to 'any given standard' (cited in Colebrook 2002: xxv). Juxtaposing these poets' concerns about the history of their peoples does not necessarily suggest that there is a mutual, or one-sided, direct impact between them, even though their poetry collections, which are discussed here, were published around the same period. The similarities that appeared in their poetic themes resulted from their adherence to an international movement of 'black' resistance and consciousness. Intersecting these poetics can open up new vectors for literary comparison and exploration.

\section{Acknowledgement}

I would like to express my sincere gratitude to my former supervisor, Professor Kay Ferres, for the guidance, encouragement and advice she provided throughout my early $\mathrm{PhD}$ candidature at Griffith University. I have been extremely lucky to work with my current supervisors, Dr Stuart Cooke and Professor Chris Lee, who care so much about my work, and are responding to my questions and inquiries so promptly. I would also like to extend my gratitude to the Higher Committee for Education Development in Iraq for their financial support.

\section{Endnotes}

1 For Aboriginal peoples, 'The academic concept of History itself ... is a European one; it is fundamentally at odds with the Aboriginal notion of Dreaming, of mythic timelessness. Therefore, for an Aboriginal writer to adopt a Western view of history - of history as a linear course of events - is in itself a compromise' (Nelson 1990: 32; see also Muecke 2004: 24).

2 Stuart Cooke (2013: 62) also refers to a similar, but literary, kind of historical conflation in his discussion of Judith Wright's poem 'Two Dreamtimes'.

3 According to Schaffer and Smith (1998: xx), recent studies in archaeology, such as that of Josephine Flood (1989), 'have pushed the date back even further and presented the claim that indigenous people may have inhabited the continent for 175,000 years'.

4 George Lipsitz (1990: 213) distinguishes 'counter-memory' from historical narratives. The latter 'begin with the totality of human existence and then locate specific actions and events within that totality ... Counter-memory looks to the past for the hidden histories excluded from dominant narratives.'

5 The complete title of this poem is 'To Fanon, culture meant only one thing - an environment shaped to help us \& our children grow, shaped by ourselves in action against the system that enslaves us'.

\section{References}

Attwood, B. \& Markus, A. 1999. The struggle for Aboriginal rights: A documentary history. Sydney: Allen \&Unwin.

Bensmai'a, Réda 1986. 'Foreword: The Kafka effect' in Gilles Deleuze and Félix Guattari (eds), Kafka: Towards a minor literature. Trans. Dana Polan. Minneapolis, MN: University of Minnesota Press. 
Berlin, Ira 2010. Cracking the code of human genome: The changing definition of African-American. Smithsonian Magazine, http://www.smithsonianmag.com/ history/the-changing-definition-of-african-american-4905887, accessed 20 February 2018.

Cooke, Stuart 2013. Speaking the Earth's languages: A theory for Australian-Chilean postcolonial poetics. New York: Rodopi Books.

Coates, Ta-Nehisi 2015. Between the world and me. Melbourne: Text.

Cochrane, Kathie 1994. Oodgeroo. Brisbane: University of Queensland Press.

Colebrook, Claire 2002. Understanding Deleuze. Sydney: Allen \& Unwin.

'Cracker' 2017. In Oxford Learner's Dictionaries, http://www. oxfordlearnersdictionaries.com/definition/english/cracker?q=cracker, accessed 20 February 2018.

Cunneen, C. 2001. Conflict, politics and crime: Aboriginal communities and the police. Sydney: Allen \& Unwin.

Deleuze, Gilles and Guattari, Félix 1986. Kafka: Towards a minor literature. Trans. Dana Polan. Minneapolis, MN: University of Minnesota Press.

Deleuze, Gilles and Guattari, Félix 1987. A thousand plateaus: Capitalism and schizophrenia. Trans B. Massumi. Minneapolis, MN: University of Minnesota Press.

Eaton, K. C. 2008. Womanism, literature, and the transformation of the black community, 1965-1980. New York: Routledge.

Fox, Karen 2008. Oodgeroo Noonuccal: Media snapshots of a controversial life. In P. Read, F. Peters-Little and A. Haebich (eds), Indigenous biography and autobiography. Canberra: ANU e-Press, 57-68.

Fanon, F. 1963. The wretched of the earth. New York: Grove Press.

Flood, Josephine 1989. Archeology of the Dreamtime. Sydney: Angus \& Robertson.

Foley, Gary 2000. 'Assimilating the natives in the US and Australia',http://www.kooriweb.org/gst/genocide/essay_15.html.

Frost, Elizabeth A. 2005. Feminist avant-garde in American poetry. Iowa City, IA: University of Iowa Press.

Glissant, Édouard 1997. Poetics of relation. Trans Betsy Wing. Ann Arbor, MI: University of Michigan Press.

Griffiths, T. 2016. The art of time travel: Historians and their craft. Melbourne: Black Inc.

Hill, R. W. 2006. 'Representation and problems for Indigenous North American agency'. Paper presented to Rethinking Nordic Colonialism conference, Rovaniemi, Finland, 16 June to 9 July.

Hooks, B. 1995. Killing rage: Ending racism. New York: Henry Holt and Co.

Hodge, Bob 1994. 'Poetry and politics in Oodgeroo: Transcending the difference'. In Adam Shoemaker (ed.), Oodgeroo: A tribute. Brisbane: University of Queensland Press, 63-76.

Knudsen, A. R. 1994. 'From Kath Walker to Oodgeroo Noonuccal Ambiguity and assurance'. In Adam Shoemaker ed.), Oodgeroo: A tribute. Brisbane: University of Queensland Press, 105-20.

Lindquist, S. 1997. The skull measurer's mistake: And other portraits of men and women who spoke out against racism. New York: The New Press. 
Lipsitz, George 1990. Time passages: Collective memory and American popular culture. Minneapolis, MN: University of Minnesota Press.

Lothian, Kathy 2005. 'Seizing the time: Australian Aborigines and the influence of the Black Panther party', 1969-1972. Journal of Black Studies 35(4): 179-200.

Melhem, D. H. 1985. 'Sonia Sanchez: Will and spirit.' MELUS 12(3): 73-98.

Martin, Ben L. 1991. 'From negro to black to African American: The power of names and naming'. Political Science Quarterly 106(1): 83-107.

Mead, Philip 2008. Networked language: Culture \& history in Australian Poetry. Melbourne: Australian Scholarly Publishing.

Medina, José 2011. 'Toward a Foucaultian epistemology of resistance: Countermemory, episte-mic friction, and guerrilla pluralism'. Foucault Studies 12: 9-35.

Malcolm, X 1965. The autobiography of Malcolm X. Ringwood: Penguin.

Muecke, Stephen 2004. Ancient \& modern: Time, culture and indigenous philosophy. Sydney: UNSW Press.

Nelson, Emmanuel S. 1990. 'Literature against history: An approach to Australian Aboriginal writing'. World Literature Today 64(1): 30-4.

Neumann, Klaus 1992. 'A postcolonial writing of Aboriginal history. Meanjin 51(2): pp. 277-98.

Neal, Larry 1968. 'The black arts movement'. The Drama Review: TDR 12(4): 29-39.

Pate, Alexs 2010. In the heart of the beat: The poetry of rap: African American cultural theory and heritage. Lanham, MD: Scarecrow Press.

Ruchames, Louis (ed.) 1970. Racial thought in America: From the Puritans to Abraham Lincoln. New York: Grosset \& Dunlap.

Schaffer, K. and Smith, S. 1998. 'Introduction'. In J. Sabbioni, K. Schaffer and S. Smith (eds), Indigenous Australian voices: A reader. New Brunswick, NJ: Rutgers University Press.

Sanchez, Sonia 1970. We a baddDDD people. Detroit, MI: Broadside Press.

Sanchez, Sonia 1969. Home Coming: Poems by Sonia Sanchez. Detroit, MI: Broadside Press.

Shoemaker, Adam 2004. Black words white page: Aboriginal literature 1929-1988. Canberra: Australian National University.

Sitter, D. A. 2001. 'Sanchez, Sonia'. In W. L. Andrews, F. S. Foster and T. Harris (eds), The concise Oxford companion to African American literature. New York: Oxford University Press.

Tyson, L. 2006. Critical literary theory: A user-friendly guide (2nd ed.). New York: Routledge.

Waldrep, C. 2009. African Americans confront lynching: Strategies of resistance from the civil war to the civil rights era. Lanham, MC: Rowman \& Littlefield.

Walker, Kath 1964. We are going. Brisbane: Jacaranda.

Walker, Kath 1970. My people: A Kath Walker collection. Brisbane: Jacaranda. 